\title{
The Response of the Soil Microbiome to Contamination with Cadmium, Cobalt and Nickel in Soil Sown with Brassica napus
}

\author{
Edyta Boros-Lajszner, Jadwiga Wyszkowska *(D), Agata Borowik (D) and Jan Kucharski (D) \\ Department of Soil Science and Microbiology, University of Warmia and Mazury in Olsztyn, Plac Łódzki 3, \\ 10-727 Olsztyn, Poland; edyta.boros@uwm.edu.pl (E.B.-L.); agata.borowik@uwm.edu.pl (A.B.); \\ jan.kucharski@uwm.edu.pl (J.K.) \\ * Correspondence: jadwiga.wyszkowska@uwm.edu.pl; Tel.: +48-89-523-4938
}

check for updates

Citation: Boros-Lajszner, E.; Wyszkowska, J.; Borowik, A.; Kucharski, J. The Response of the Soil Microbiome to Contamination with Cadmium, Cobalt and Nickel in Soil Sown with Brassica napus. Minerals 2021, 11, 498. https://doi.org/ $10.3390 / \min 11050498$

Academic Editors: Anna Karczewska and Karolina Lewińska

Received: 29 March 2021

Accepted: 6 May 2021

Published: 8 May 2021

Publisher's Note: MDPI stays neutral with regard to jurisdictional claims in published maps and institutional affiliations.

Copyright: (c) 2021 by the authors. Licensee MDPI, Basel, Switzerland. This article is an open access article distributed under the terms and conditions of the Creative Commons Attribution (CC BY) license (https:// creativecommons.org/licenses/by/ $4.0 /)$.

\begin{abstract}
Soil fertility is determined by biological diversity at all levels of life, from genes to entire biocenoses. The aim of this study was to evaluate bacterial diversity in soil contaminated with $\mathrm{Cd}^{2+}$, $\mathrm{Co}^{2+}$ and $\mathrm{Ni}^{2+}$ and sown with Brassica napus. This is an important consideration because soil-dwelling microorganisms support phytoremediation and minimize the adverse effects of heavy metals on the environment. Microbial counts, the influence $\left(\mathrm{IF}_{\mathrm{HM}}\right)$ of $\mathrm{Cd}^{2+}, \mathrm{Co}^{2+}$ and $\mathrm{Ni}^{2+}$ on microorganisms, the colony development (CD) index, the ecophysiological diversity (EP) index and genetic diversity of bacteria were determined under controlled conditions. Soil contamination with $\mathrm{Cd}^{2+}, \mathrm{Co}^{2+}$ and $\mathrm{Ni}^{2+}$ significantly influenced microbial diversity and increased the values of CD and EP indices. The tested heavy metals decreased the genetic diversity of bacteria, in particular in the phyla Actinobacteria and Proteobacteria. Bacteria of the genera Arthrobacter, Devosia, Kaistobacter, Paenibacillus, Phycicoccus, Rhodoplanes and Thermomonas were identified in both contaminated and non-contaminated soil. These bacteria are highly resistant to soil contamination with $\mathrm{Cd}^{2+}, \mathrm{Co}^{2+}$ and $\mathrm{Ni}^{2+}$.
\end{abstract}

Keywords: soil; heavy metals; ecophysiological diversity; genetic diversity

\section{Introduction}

Environmental stress caused by various pollutants, including heavy metals, has a negative effect on the biological activity of soil. Any changes in environmental conditions can modify the composition of soil-dwelling microorganisms and their activity [1]. Biological diversity should be preserved and changes that take place at all levels of life, including microorganisms that occupy the lowest level of the trophic system, have to be monitored to maintain ecosystem health [2]. Microorganisms constitute the largest group of soil-dwelling organisms. They participate in the circulation of elements in nature, including carbon, nitrogen, sulfur and phosphorus, the decomposition of organic matter, energy flow and they influence the physical parameters of soil and soil structure [3-5]. Unlike organic pollutants, heavy metals do not undergo microbial decomposition [6] and their total concentrations in soil persist for a long time after deposition [7]. Heavy metals lead to the biological and chemical degradation of soil [8]. They exert a negative effect on microbial populations and the activity of soil enzymes. Heavy metals disrupt not only microbial diversity, but also biochemical processes $[9,10]$. Natural and anthropogenic changes in the environment elicit quick responses from microorganisms which, due to their sensitivity, can rapidly adapt to new conditions. Microorganisms have developed defense mechanisms that minimize the toxic effects of heavy metals [11]. These mechanisms involve extracellular and intracellular binding of trace elements. The most widely encountered extracellular mechanisms which eliminate heavy metals include ATP-binding cassettes $(\mathrm{ABC})$, inner membrane transporters of the resistance-nodulation-division (RND) family, small multidrug resistance (SMR) proteins, major facilitator superfamily (MFS) proteins and multidrug and toxic compound extrusion (MATE) proteins [12,13]. Intracellular binding mechanisms involve metallothionein proteins with high affinity for divalent cations 
such as $\mathrm{Cu}^{2+}, \mathrm{Zn}^{2+}, \mathrm{Co}^{2+}$ and $\mathrm{Cd}^{2+}$ [14]. Metallothioneins contain cysteine residues with four $\mathrm{Zn}^{2+}$ or $\mathrm{Cd}^{2+}$ binding sites. Histidine residues containing nitrogen play a supporting role in this process [15-18]. Other defense mechanisms include decreased permeability of cell envelopes or membranes to trace mineral ions, metal transport outside cells, decreased sensitivity of cell organelles to heavy metals and enzymatic detoxification of metals to less toxic forms. Microorganisms harbor one or several of these mechanisms [13]. Microbial resistance to heavy metals is encoded mainly by plasmids that harbor operons. Plasmids can be located on chromosomes or transposons and they participate in the horizontal transfer of genes that encode resistance to heavy metals [19]. This mechanism contributes to the formation and spread of metal-resistant populations that can dominate nearly all microorganisms in a given environment [20]. Extracellular and intracellular defense bonds prevent metals from entering cells. The first type of bonds immobilizes metal ions and prevents them from penetrating cells. Exopolysaccharides play a key role in this defense mechanism because their chemical structure supports non-specific metal binding [13]. Microorganisms can also minimize the toxic effects of trace elements by inducing changes in the structure of the cell wall or membrane, which prevents metals from entering the cell [21]. Cell envelopes can bind metals non-specifically until their binding sites are fully saturated. This defense mechanism relies on peptidoglycan, the main cell wall component in Grampositive bacteria and lipopolysaccharide in Gram-negative bacteria. In fungi, metals can be bioabsorbed by chitin and other polysaccharides such as mannans and glucans [21,22]. Toxic compounds are also removed from cells by the efflux pump mechanism which is characterized by high specificity for the evacuated metals [12,23]. The extent to which microorganisms adapt to new conditions can be evaluated by monitoring quantitative and qualitative changes in microbial populations and their activity [24]. The changes observed in microbial populations reflect the combined influence of physical, chemical and biological factors on soil ecosystems [25].

Heavy metal pollution negatively affects the growth and development of plants. Nickel compromises germination capacity [26], root growth and branching [27] and nutrient uptake [28]; it damages the photosynthetic apparatus [29] and causes oxidative stress [30]. Cobalt causes early leaf drop; it inhibits the growth and development of the assimilative apparatus and promotes leaf chlorosis [31]. Excess cadmium decreases nutrient uptake by plants [32] and reduces enzyme activity [33]. Plants have also developed a number of mechanisms that enable their survival under stress conditions, in environments contaminated with heavy metals. Metallophytes, namely plants that tolerate high levels of heavy metals, have evolved on mineral substrates (including substrates that contain metals) $[34,35]$. Pseudometallophytes are plants that grow on both uncontaminated soils and soils contaminated with heavy metals [36]. Specific transporters and systems for transporting minerals required for plant growth (phosphorus, calcium) enable plants to take up and accumulate metals [34]. These mechanisms reduce the concentrations of trace elements in soil, but metals can be taken up only in a form that is available to plants. Therefore, the extent to which heavy metals can be removed from plants is determined mainly by their bioavailability [37].

This study involved Brassica napus, a crop plant that can be easily processed for purposes other than food and feed production, including for energy generation. Brassica napus is characterized by rapid growth and high biomass yield. This crop can be grown on soils contaminated with heavy metals and it has numerous industrial uses, including in the production of biodiesel. In view of the above, the aim of this study was to determine and compare the effects of $\mathrm{Ni}^{2+}, \mathrm{Co}^{2+}$ and $\mathrm{Cd}^{2+}$ contamination on microbial diversity in soil sown with Brassica napus. The research hypothesis postulating that soil contamination with these heavy metals induces changes in the structure of microbial communities was tested. 


\section{Materials and Methods}

2.1. Soil

The experiment was performed on soil with $\mathrm{pH}_{\mathrm{KCl}} 7.00$ and granulometric composition of sandy loam (size fraction $<0.002 \mathrm{~mm}-2.88 \%$, size fraction $0.020-0.050 \mathrm{~mm}-27.1 \%$, size fraction $0.050-2.000 \mathrm{~mm}-69.4 \%$ ). Soil samples were collected in Tomaszkowo in the Masurian Lakeland in north-eastern Poland $\left(53.7196^{\circ} \mathrm{N}, 20.3969^{\circ} \mathrm{E}\right)$. The analyzed sandy loam had the following physicochemical parameters: $C_{\text {org }}-6.90 \mathrm{~g} \mathrm{~kg}^{-1}, \mathrm{~N}_{\text {total }}$ $0.11 \mathrm{~g} \mathrm{~kg}^{-1}, \mathrm{HAC}-7.00 \mathrm{mmol}^{(+)} \mathrm{kg}^{-1}, \mathrm{EBC}-31.0 \mathrm{mmol}^{(+)} \mathrm{kg}^{-1}, \mathrm{CEC}-38.5 \mathrm{mmol}^{(+)} \mathrm{kg}^{-1}$, BS- $80.5 \%$. The Masurian Lakeland has a diverse landform that was created by meltwater, erosion, accumulation of rivers, lakes and weathering during the last glacial period. The region is characterized by soils with moderate to low fertility, mostly podzols and brown soils formed on sand and glacial till.

\subsection{Experimental Design}

A pot experiment was established in a greenhouse (Poland) with four replications. In the first stage, soil samples of $3.5 \mathrm{~kg}$ each were passed through a sieve with $1 \mathrm{~cm}$ mesh size. In the second stage, soil samples were contaminated with nickel, cobalt and cadmium chlorides at $\mathrm{Ni}^{2+}-400 \mathrm{mg} \mathrm{kg}^{-1}, \mathrm{Co}^{2+}-80 \mathrm{mg} \mathrm{kg}^{-1}$ and $\mathrm{Cd}^{2+}-8 \mathrm{mg} \mathrm{kg}^{-1}$. Each treatment had 4 replicates $(n=16)$. Heavy metal doses were established based on the Regulation of the Minister of the Environment [38] and soil contamination levels in Poland [39-42] and other European Union countries and the world [43,44]. In Polish soils, the average content of $\mathrm{Ni}^{2+}$ has been estimated at $20 \mathrm{mg} \mathrm{kg}^{-1}$ [39]. Soil contamination with $\mathrm{Ni}^{2+}$ does not occur frequently around the world, but in some areas, human activity has led to excessive $\mathrm{Ni}^{2+}$ accumulation in soil. High levels of soil contamination with $\mathrm{Ni}^{2+}$ have been reported near the Sudbury steel mill in Canada (1600-2150 $\left.\mathrm{mg} \mathrm{kg}^{-1}\right)[45,46]$, in the vicinity of the non-ferrous metal factory in Plovdiv, Bulgaria (303 $\mathrm{mg} \mathrm{kg}^{-1}$ ) [47], Selebi Phikwe copper-nickel mine in Botswana (267 mg kg ${ }^{-1}$ ) [48], the former sewage sludge landfill in Denmark (212 $\mathrm{mg} \mathrm{kg}^{-1}$ ) [49] and a defunct waste incineration plant in the Czech Republic (122 $\mathrm{mg} \mathrm{kg}^{-1}$ ) [50]. The geochemical background value of cobalt in soils has been determined at $6.5 \mathrm{mg} \mathrm{kg}^{-1} \mathrm{DM}$ in Poland and at $4.5-12 \mathrm{mg} \mathrm{kg}^{-1} \mathrm{DM}$ around the world [39]. Point-source pollution with cobalt has also been reported in Japan $\left(23 \mathrm{mg} \mathrm{kg}^{-1}\right.$ soil) [51], Egypt (26.8 $\left.\mathrm{mg} \mathrm{kg}^{-1}\right)$ [52], Sweden $\left(14 \mathrm{mg} \mathrm{kg}^{-1}\right)$ [53], in the vicinity of nonferrous metal ore mines in southern Sardinia (30-495 kg-1 DM) [54] and non-ferrous metal factories in the USA ( $>154 \mathrm{mg} \mathrm{kg}^{-1}$ ) [39]. Natural cadmium levels range from 0.06 to $1.1 \mathrm{mg} \mathrm{kg}^{-1}$ in Polish soils [39] and from 0.2 to $1.3 \mathrm{mg} \mathrm{kg}^{-1}$ in European soils [55]. In locally contaminated soils in the USA (Arizona), cadmium deposition was determined at $394 \mathrm{mg} \mathrm{kg}^{-1}$ to $1777 \mathrm{mg} \mathrm{kg}^{-1}$ [56]. In urban soils, cadmium concentrations were determined at $6.7 \mathrm{mg} \mathrm{kg}^{-1}$ in Pakistan, $2.6 \mathrm{mg} \mathrm{kg}^{-1}$ in Iran and $1.2 \mathrm{mg} \mathrm{kg}^{-1}$ in Denmark. In agricultural soils fertilized with sewage sludge, cadmium levels reached $19.3 \mathrm{mg} \mathrm{kg}^{-1}$ in India, around $3.5 \mathrm{mg} \mathrm{kg}^{-1}$ in Pakistan, $2.5 \mathrm{mg} \mathrm{kg}^{-1}$ in Zimbabwe and around $2.0 \mathrm{mg} \mathrm{kg}^{-1}$ in Serbia, Egypt and Mexico [57]. Brassica napus plants were fertilized with the following macronutrients: $\mathrm{N}-70 \mathrm{mg} \mathrm{kg}^{-1}$ soil DM, P-30 $\mathrm{mg} \mathrm{kg}^{-1}$ soil DM, K-56 $\mathrm{mg} \mathrm{kg}^{-1}$ soil DM and $\mathrm{Mg}-10 \mathrm{mg} \mathrm{kg}^{-1}$ soil DM. Fertilizers were applied in the following form: nitrogen$\mathrm{CO}\left(\mathrm{NH}_{2}\right)_{2}$, phosphorus- $\mathrm{KH}_{2} \mathrm{PO}_{4}$, potassium- $\mathrm{KCl}$ and magnesium- $\mathrm{MgSO}_{4} \cdot 7 \mathrm{H}_{2} \mathrm{O}$. $\mathrm{CO}\left(\mathrm{NH}_{2}\right)_{2}$ contained $46.6 \% \mathrm{~N}, \mathrm{KH}_{2} \mathrm{PO}_{4}-22.8 \% \mathrm{P} ; \mathrm{KCl}-52.4 \% \mathrm{~K}$, and $\mathrm{MgSO}_{4} \cdot 7 \mathrm{H}_{2} \mathrm{O}-$ $9.9 \% \mathrm{Mg}$. Soil samples were combined with fertilizers, placed in polyethylene pots and brought to capillary water capacity of $50 \%$. Soil not contaminated with heavy metals but fertilized with macronutrients was the control. The following soil treatments were analyzed: (1) uncontaminated soil (control), (2) soil contaminated with $\mathrm{Ni}^{2+}$, (3) soil contaminated with $\mathrm{Co}^{2+}$ and (4) soil contaminated with $\mathrm{Cd}^{2+}$. The average ambient temperature was $16.5{ }^{\circ} \mathrm{C}$, air humidity was $77.5 \%$ and daytime length ranged from $14 \mathrm{~h} 4 \mathrm{~min}$ to $16 \mathrm{~h} 30 \mathrm{~min}$. The following soil treatments were analyzed: uncontaminated soil and soil contaminated with cadmium, cobalt and nickel. The emerged seedlings were thinned and six Brassica napus plants were left per pot. The plants were harvested during flowering (BBCH $60-$ 
Biologische Bundesanstalt Bundessortenamt und Chemical Scale). The experiment lasted 50 days. Soil samples for analyses of microbiological properties were collected in the same period.

\subsection{Method of Microbiological Analysis}

The counts of organotrophic bacteria, actinobacteria and fungi were determined by the serial dilution method. Soil samples (10 g) were placed in sterile isotonic saline solution $\left(90 \mathrm{~cm}^{3} 0.85 \% \mathrm{NaCl}\right)$ and shaken for $30 \mathrm{~min}(130 \mathrm{rpm})$. One $\mathrm{cm}^{3}$ of each serial solution and $18 \mathrm{~cm}^{3}$ of a selective medium were placed in sterile Petri dishes and incubated in a thermostat at a temperature of $28{ }^{\circ} \mathrm{C}$ for 10 days. Colony forming units (cfu) were counted daily for 10 days. Microbiological analyses were carried out according to the procedures described by Boros-Lajszner et al. [58]. The growth rate of various microbial groups (organotrophic bacteria, actinobacteria and fungi) and the number of emerged microbial colonies were determined to calculate the colony development (CD) index and the ecophysiological diversity (EP) index in uncontaminated soil and in soil contaminated with $\mathrm{Ni}^{2+}, \mathrm{Co}^{2+}$ and $\mathrm{Cd}^{2+}$. The microbial $\mathrm{CD}$ index was calculated based on the formula developed by De Leija et al. [59] and the EP index, based on the formula proposed by Sarathchandra et al. [60].

The microbial CD index was calculated with the use of the following formula:

$$
\mathrm{CD}=\left[\frac{\mathrm{N}_{1}}{1}+\frac{\mathrm{N}_{2}}{2}+\frac{\mathrm{N}_{3}}{3} \ldots \ldots \frac{\mathrm{N} 10}{10}\right] \times 100
$$

where $\mathrm{N}_{1}, \mathrm{~N}_{2}, \mathrm{~N}_{3} \ldots \mathrm{N}_{10}$ is total number of microbial colonies on experimental days 1, 2, 3 10 divided by the total number of colonies identified during the entire experimental period.

The microbial EP index was determined with the following formula:

$$
\mathrm{EP}=-\Sigma(\mathrm{pi} \cdot \log \mathrm{pi})
$$

where pi is the number of microbial colonies on a given day divided by the total number of colonies.

The influence of heavy metals $\left(\mathrm{IF}_{\mathrm{Hm}}\right)$ on microbial counts and Brassica napus was determined with the use of the following formula:

$$
\mathrm{IF}_{\mathrm{HM}}=\frac{\mathrm{A}_{\mathrm{HM}}}{\mathrm{A}_{0}}-1
$$

where $\mathrm{IF}_{\mathrm{Hm}}$ - heavy metal pollution index,

$\mathrm{A}_{\mathrm{Hm}}-$ microbial counts/number of plants in soil contaminated with heavy metals,

$\mathrm{A}_{0}$ - microbial counts/number of plants in uncontaminated soil.

DNA was isolated from the rhizosphere of Brassica napus with the Genomic Mini AX Bacteria + kit. The polymerase chain reaction was carried out with the Q5 Hot Start Hight-Fidelity 2X Master Mix according to the manufacturer's instructions. A metagenomic analysis of the 16S rRNA coding gene was performed based on the sequence of the V3V4 hypervariable region of $16 \mathrm{~S}$ rRNA. The selected region was amplified and a library was developed with the use of specific polymer sequences $341 \mathrm{~F}$ and $785 \mathrm{R}$. Data were collected and standardized in the last stage of library development. The 16S rRNA gene was sequenced in the MiSeq Reporter (MSR) v 2.6 program with $2 \times 250$ bp paired-end runs in Illumina $v 2$. The reads were identified to the genus level in the QIIME program based on the GreenGenes v 13.8 reference database. Sequencing was performed by Genomed SA (Warsaw, Poland).

\subsection{Statistical Analysis}

Data were processed statistically in Statistica 13.1 (Palo Alto, CA, USA) [61]. The results were compared in ANOVA and Tukey's HSD test. Homogeneous groups were 
identified at a significance level of $p=0.05$. The analyzed data had normal distribution and similar variance. Metagenomic profiles were analyzed in STAMP 2.1.3. [62] and Circos 0.68 software [63]. The number of operational taxonomic units (OTUs) associated with each class and order was directly proportional to each bandwidth combining bacterial taxa with the corresponding soil samples. Each bacterial class and order were represented by a unique color. The external ring represents the total percentage of $16 \mathrm{~S}$ sequences and the internal ring denotes the number of $16 \mathrm{~S}$ amplicon sequences allocated to a given taxon.

\section{Results}

The microbiological properties of soil were modified under the influence of $\mathrm{Ni}^{2+}, \mathrm{Co}^{2+}$ and $\mathrm{Cd}^{2+}$ (Table S1). Heavy metals significantly decreased the abundance of organotrophic bacteria and fungi, but their influence on actinobacteria was less pronounced. These observations were confirmed by the values of the heavy metal pollution index $\left(\mathrm{IF}_{\mathrm{HM}}\right)$ (Figure 1). $\mathrm{Ni}^{2+}$ followed by $\mathrm{Co}^{2+}$ and $\mathrm{Cd}^{2+}$ exerted the greatest negative effect on the soil microbiome, in particular, organotrophic bacteria and fungi. Actinobacteria were least sensitive to heavy metal contamination.

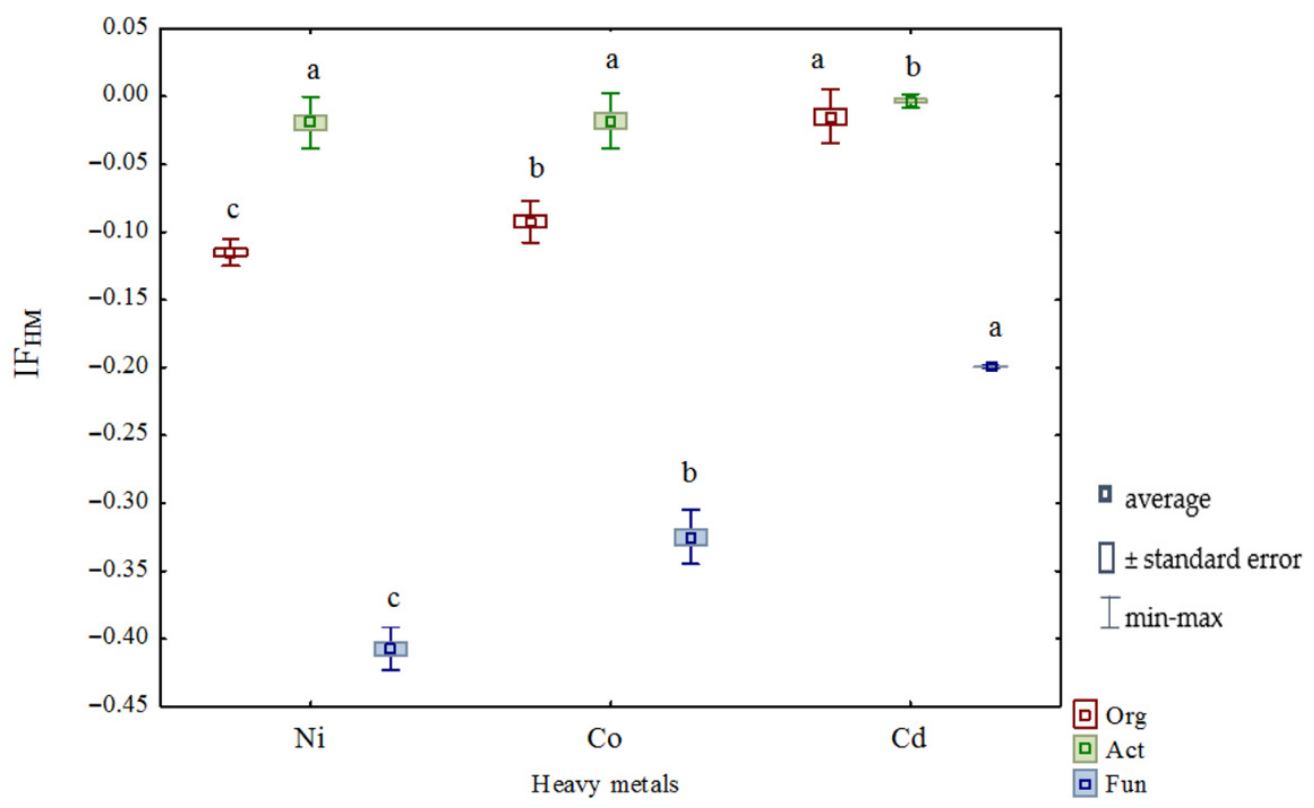

Figure 1. The influence of heavy metals $\left(\mathrm{IF}_{\mathrm{HM}}\right)$ on microbial counts in soil. Org-organotrophic bacteria; Act—actinobacteria; Fun—fungi. Cd—soil contaminated with cadmium; Co—soil contaminated with cobalt; $\mathrm{Ni}$ - soil contaminated with nickel. Identical letters $(\mathrm{a}-\mathrm{c})$ in columns denote the same homogeneous groups.

In soil contaminated with nickel, the colony development $(\mathrm{CD})$ index of organotrophic bacteria $(C D=52.8)$ was higher and the $C D$ index of actinobacteria $(C D=26.3)$ and fungi $(\mathrm{CD}=38.2)$ (Figure 2) was lower than in the control treatment. The ecophysiological diversity (EP) index of organotrophic bacteria, actinobacteria and fungi was significantly higher in soil contaminated with heavy metals (Figure 2). The EP index was highest in actinobacteria, followed by organotrophic bacteria and it was lowest in fungi (EP $=0.42-0.47)$. 


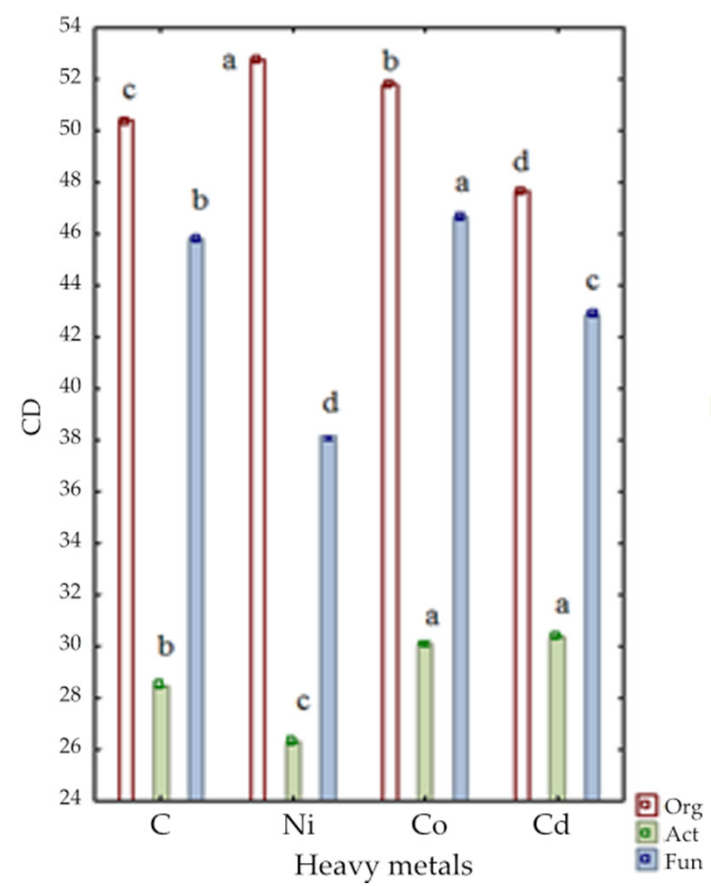

(a)

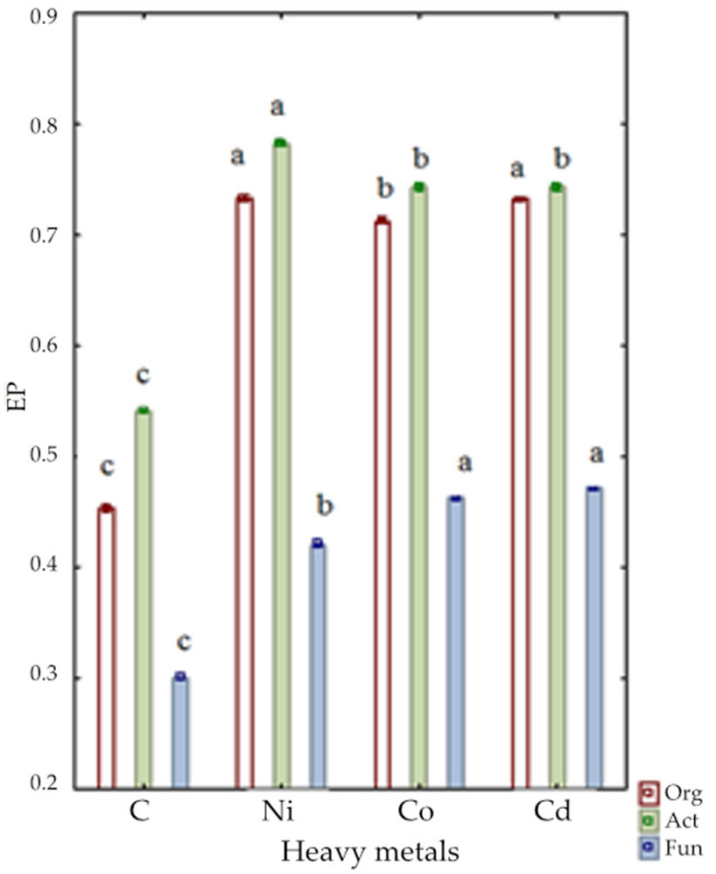

(b)

Figure 2. Microbial colony development (CD) index (a) and ecophysiological diversity (EP) index (b) in soil. C-control soil; $\mathrm{Cd}$-soil contaminated with cadmium; $\mathrm{Co}$ - soil contaminated with cobalt; $\mathrm{Ni}$-soil contaminated with nickel. Identical letters $(\mathrm{a}-\mathrm{d})$ in columns denote the same homogeneous groups.

Bacterial phyla Actinobacteria and Proteobacteria were predominant in soil samples contaminated with heavy metals (Figure 3). Actinobacteria was the dominant phylum in all treatments and it accounted for $35.6 \%$ of the microorganisms in soil contaminated with nickel, $57.3 \%$-in soil contaminated with cadmium, $61.5 \%$-in soil contaminated with cobalt and $62.5 \%$-in uncontaminated soil (Figure 3). Proteobacteria was the second most abundant phylum, which was predominant in nickel-contaminated soil (49.1\%). The phylum Actinobacteria was characterized by the greatest variations in the number of OTUs. The number of OTUs specific to Actinobacteria was $25.9 \%$ higher in soil contaminated with cobalt than nickel and it was $21.7 \%$ higher in soil exposed to cadmium than nickel.

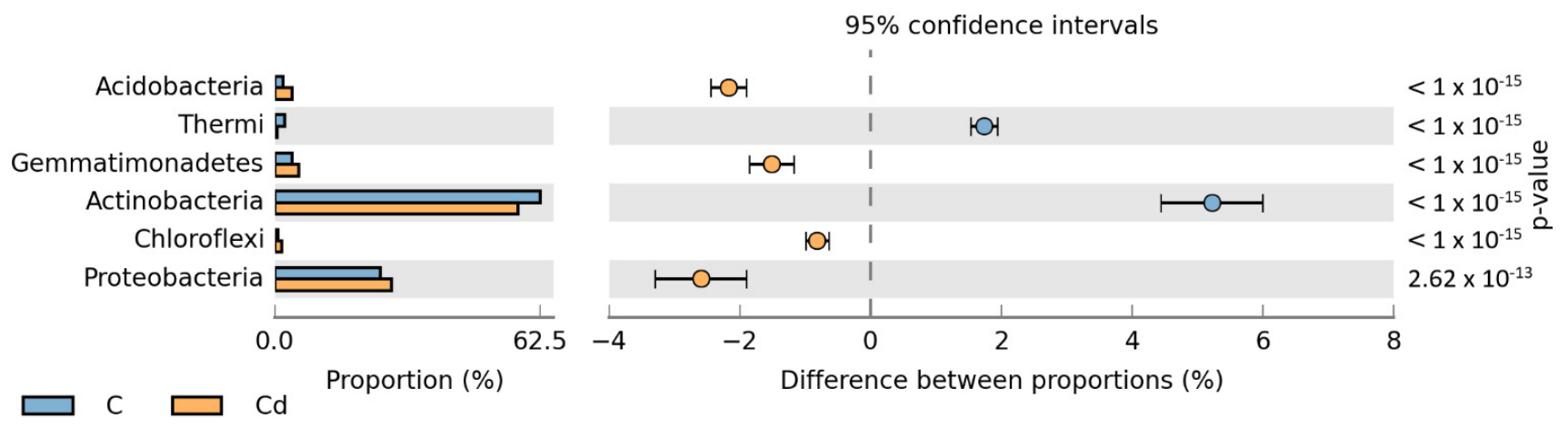

(a)

Figure 3. Cont. 


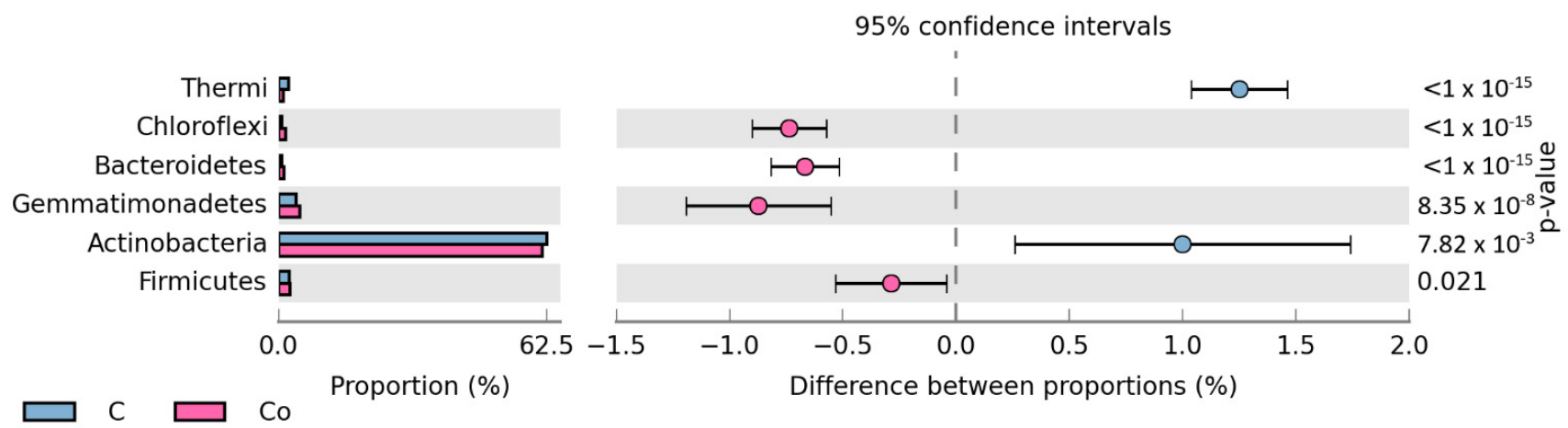

(b)

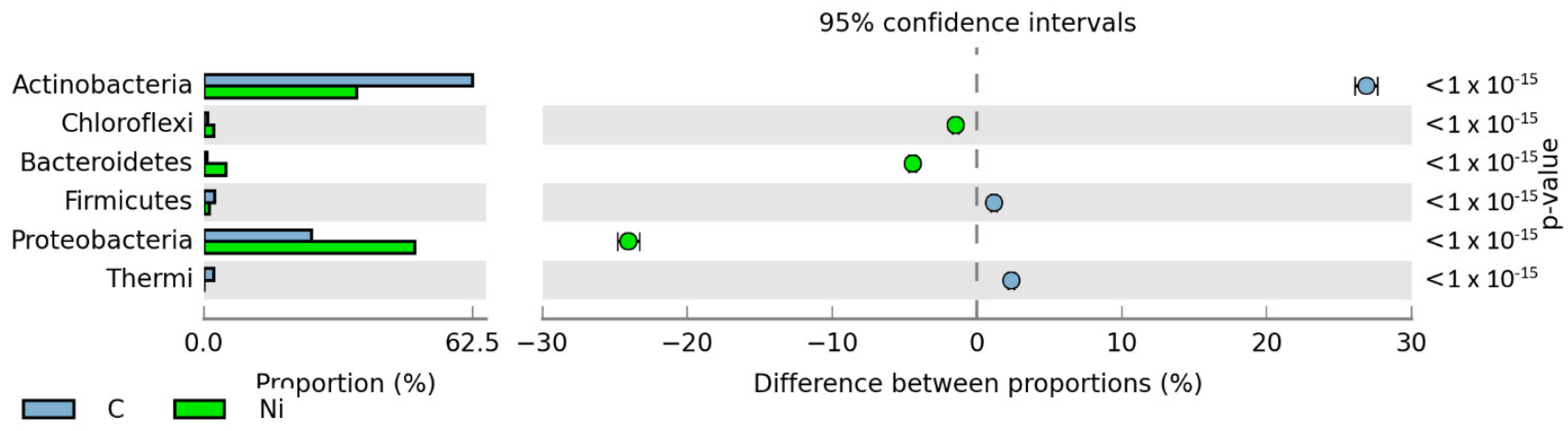

(c)

$95 \%$ confidence intervals

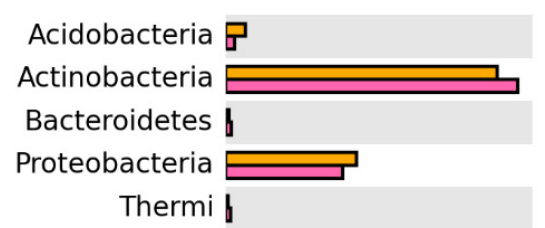

Gemmatimonadetes 日

Firmicutes $\mathrm{B}$

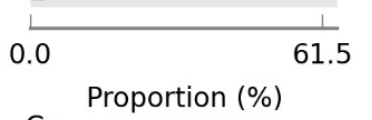

$\mathrm{Cd} \square$ Co Proportion (\%)

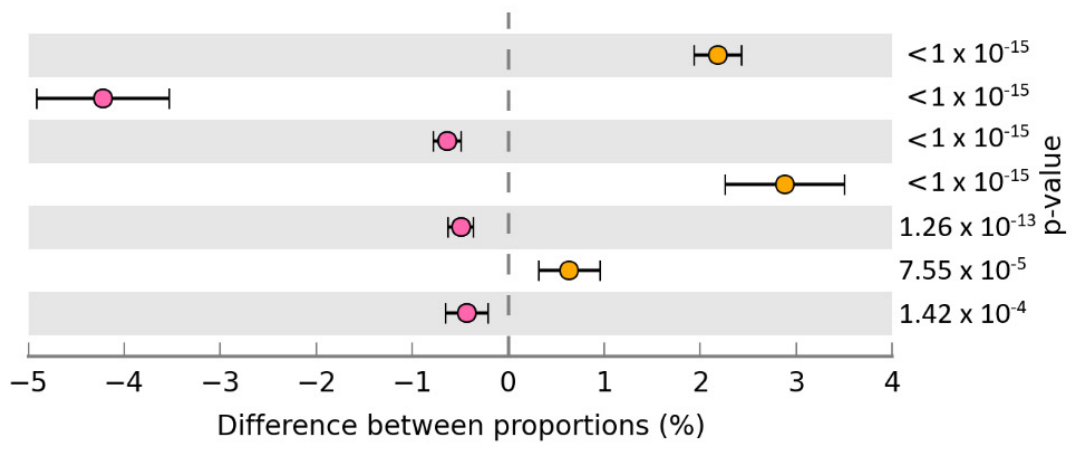

(d)

$95 \%$ confidence intervals

Acidobacteria $\square$

Actinobacteria Bacteroidetes $\hookrightarrow$

Firmicutes ?

Proteobacteria

Thermi I

Gemmatimonadetes $日$

Chloroflexi 8

$$
0.0
$$

$\mathrm{Ni}$

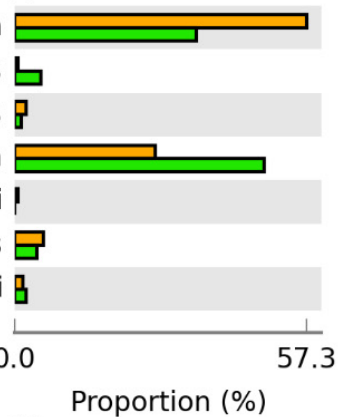

Proportion (\%)

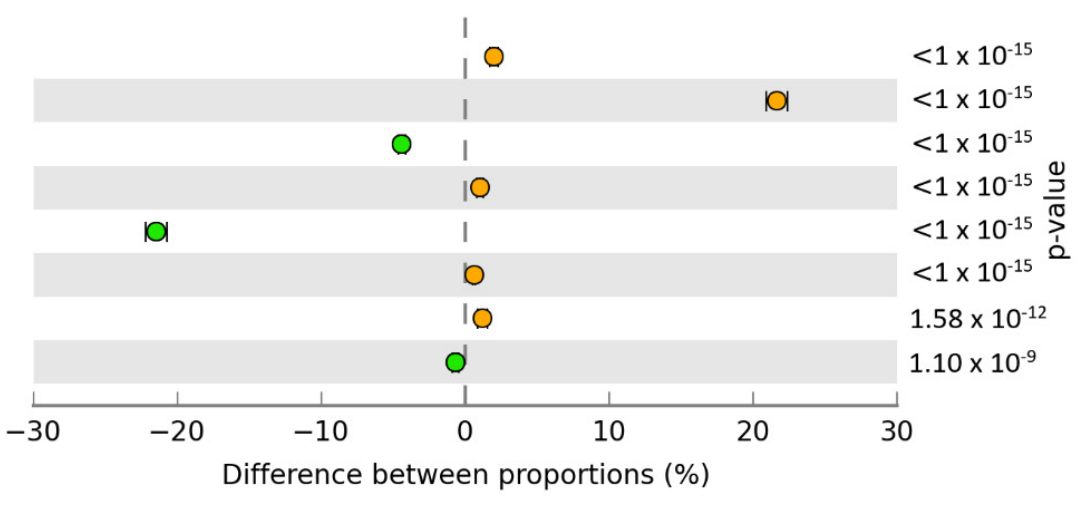

(e)

Figure 3. Cont. 


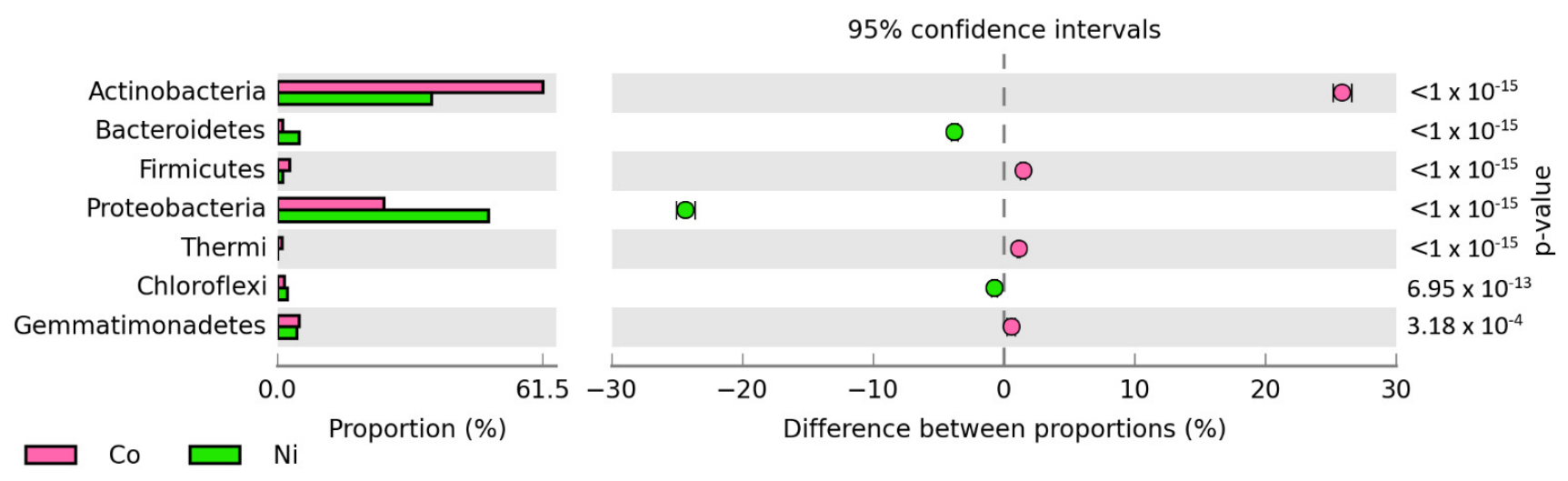

(f)

Figure 3. The relative abundance of the dominant bacterial phyla in soil, where the difference in the proportions of the dominant phyla $\geq 1 \%$. C—control soil; $\mathrm{Cd}$ - soil contaminated with cadmium; $\mathrm{Co}$-soil contaminated with cobalt; $\mathrm{Ni}-$ soil contaminated with nickel. (a): between $\mathrm{C}-\mathrm{Cd}$; (b): between $\mathrm{C}-\mathrm{Co}$; (c): between $\mathrm{C}-\mathrm{Ni}$; $(\mathbf{d})$ : between $\mathrm{Cd}-\mathrm{O}$; $(\mathbf{e})$ : between $\mathrm{Cd}-\mathrm{Ni}$; (f): between $\mathrm{Co}-\mathrm{Ni}$.

Contamination with $\mathrm{Cd}^{2+}, \mathrm{Co}^{2+}$ and $\mathrm{Ni}^{2+}$ modified the soil microbiome also at the class level (Figure S1). In uncontaminated soil and in soil contaminated with cadmium, cobalt and nickel, the highest number of OTUs were associated with the classes Actinobacteria $(55.7 \%, 47.7 \%, 52.4 \%, 18.2 \%)$, Alphaproteobacteria $(15.2 \%, 16.1 \%, 15.3 \%, 29.3 \%)$, Betaproteobacteria (5.1\%, 7.5\%, 5.3\%, 4.0\%), Thermoleophilia (5.1\%, 6.8\%, 6.9\%, 15.4\%) and Gammaproteobacteria $(4.6 \%, 4.0 \%, 4.1 \%, 15.7 \%)$, respectively. At the level of microbial classes, heavy metals (in particular, nickel relative to cadmium and cobalt) exerted the most varied effects on Actinobacteria and Gammaproteobacteria, reflected in the differences in the number of their OTUs.

In an analysis of microbial orders (Figure 4), the highest number of OTUs specific to Actinomycetales (49.7\%), Rhizobiales (8.1\%), Sphingomonadales (5.5\%), Gaiellales (6.5\%), Burkholderiales (4.7\%), iii1-15 (4.3\%) and Xanthomonadales (4.2\%) was observed in treatments contaminated with $\mathrm{Cd}^{2+}$; the highest number of OTUs specific to Actinomycetales (54.0\%), Gaiellales (6.0\%), Sphingomonadales (5.1\%) and Xanthomonadales (4.2\%) was noted in soil contaminated with $\mathrm{Co}^{2+}$; and the highest number of OTUs specific to Actinomycetales (18.8\%), Xanthomonadales (16.2\%), Rhizobiales (15.7\%), Gaiellales (13.8\%), Sphingomonadales (9.1\%) was determined in soil contaminated with $\mathrm{Ni}^{2+}$. Uncontaminated soil was characterized by a predominance of orders Actinomycetales (57.0\%), Rhizobiales (6.5\%), Sphingomonadales (6.3\%), Xanthomonadales (4.7\%), Gaiellales (4.4\%) and Burkholderiales (3.9\%).

Bacteria of the family Micrococcaceae (phylum Actinobacteria) were predominant in control soil and in treatments contaminated with $\mathrm{Cd}^{2+}$ and $\mathrm{Co}^{2+}$ (Figure 5). Under exposure to $\mathrm{Ni}^{2+}$, the number of Micrococcaceae OTUs decreased nearly 20-fold, whereas a significant increase was observed in the abundance of bacterial families Gaiellaceae, Nocardioidacea and Intrasporangiaceae of the phylum Actinobacteria, family Xanthomonadaceae of the phylum Proteobacteria and families Sphingobacteriaceae and Hyphomicrobiaceae of the phylum Bacteroidetes. The structure of bacterial communities was also modified in treatments contaminated with $\mathrm{Cd}^{2+}$ and $\mathrm{Co}^{2+}$ relative to control, but these changes were not as spectacular as those observed in $\mathrm{Ni}^{2+}$ treatments. The number of OTUs associated with bacterial families Gaiellaceae and Hyphomicrobiaceae was significantly higher in soil contaminated with $\mathrm{Cd}^{2+}$ and $\mathrm{Co}^{2+}$ than in uncontaminated soil. In turn, bacteria of the family Nocardioidaceae were more abundant in soil contaminated with cobalt than in the control treatment and in soil exposed to cadmium. 


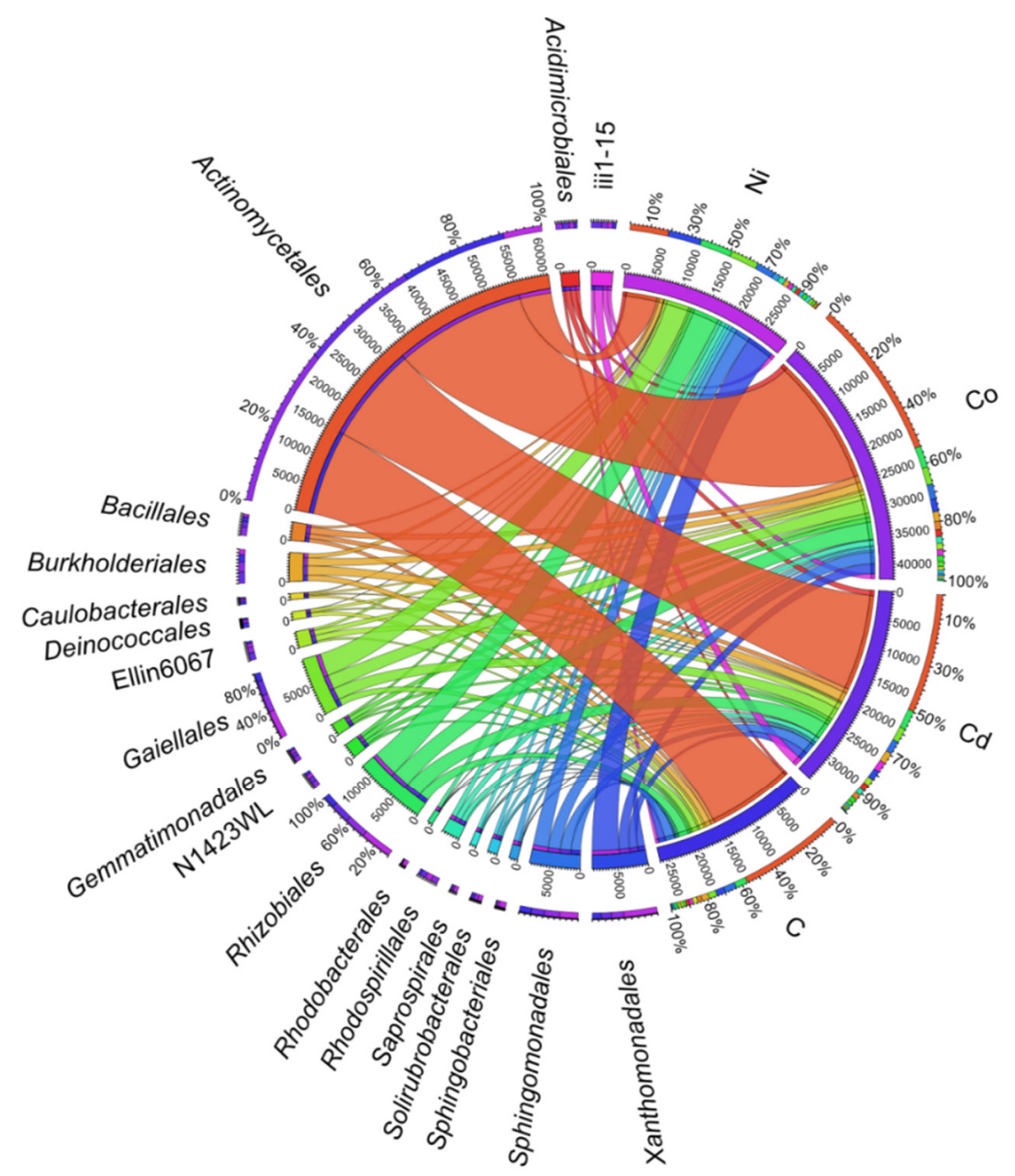

Figure 4. The relative abundance of the dominant bacterial orders in soil, where the difference in the proportions of the dominant families $\geq 1 \%$. C—control soil; Cd—soil contaminated with cadmium; $\mathrm{Co}$ - soil contaminated with cobalt; $\mathrm{Ni}$-soil contaminated with nickel.

The number of OTUs associated with specific bacterial genera exceeded $1 \%$ in eight genera (Devosia, Kaistobacter, Rhodoplanes, Thermomonas, Mesorhizobium, Lysobacter, Rhodobacter, Sphingomonas) of the phylum Proteobacteria, in two genera (Arthrobacter, Phycicoccus) of the phylum Actinobacteria, in two genera (Bacillus, Paenibacillus) of the phylum Firmicutes and in one genus (Deinococcus) of the phylum Thermi. Bacterial genera Arthrobacter, Devosia, Kaistobacter, Paenibacillus, Phycicoccus, Rhodoplanes and Thermomonas were identified in uncontaminated soil and in soil contaminated with cadmium, cobalt and nickel (Figure 6). Bacillus and Mesorhizobium were dominant in soil contaminated with $\mathrm{Cd}^{2+}, \mathrm{Co}^{2+}$ and $\mathrm{Ni}^{2+}$. Genera Lysobacter and Rhodobacter were most abundant in soil exposed to nickel. The number of OTUs specific to Deinococcus was highest in control soil and in treatments contaminated with cadmium and cobalt, whereas the abundance of Sphingomonas was highest in the control treatment and in soil contaminated with $\mathrm{Ni}^{2+}$. The correlation coefficients presented in Table S2 confirmed the presence of significant correlations between the microbial community and Brassica napus yields. Plant yields were positively correlated with the counts of all microbial groups and the colony development (CD) index of actinobacteria and fungi and they were negatively correlated with the $\mathrm{CD}$ index of organotrophic bacteria, the ecophysiological diversity (EP) index of actinobacteria and the Shannon-Wiener index describing the diversity of bacterial communities at the phylum, class, order and family level. 


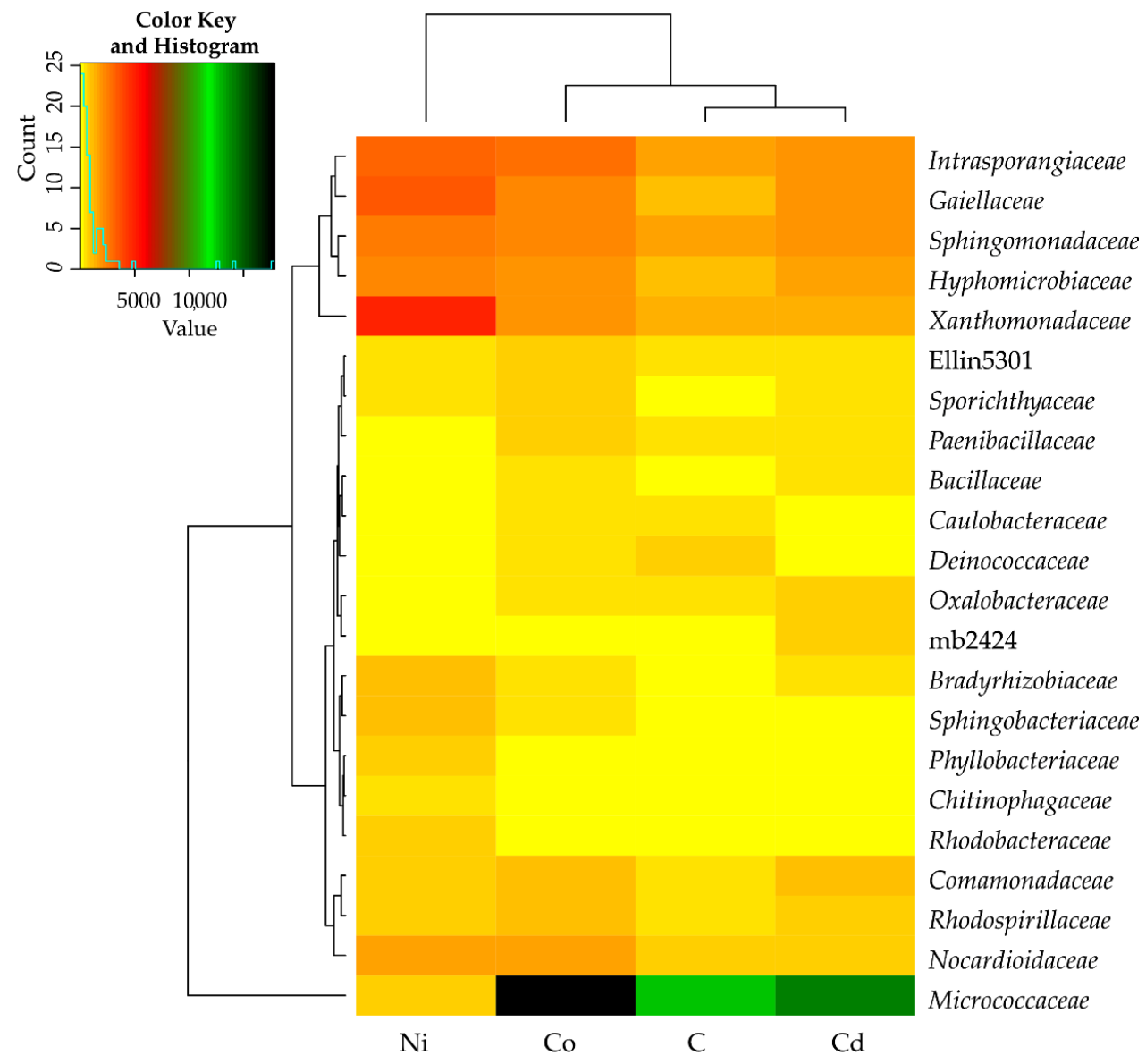

Figure 5. The relative abundance of the dominant bacterial families in soil, where the difference in the proportions of the dominant families $\geq 1 \%$. C—control soil; $\mathrm{Cd}-$ soil contaminated with cadmium; Co-soil contaminated with cobalt; $\mathrm{Ni}-$ soil contaminated with nickel.

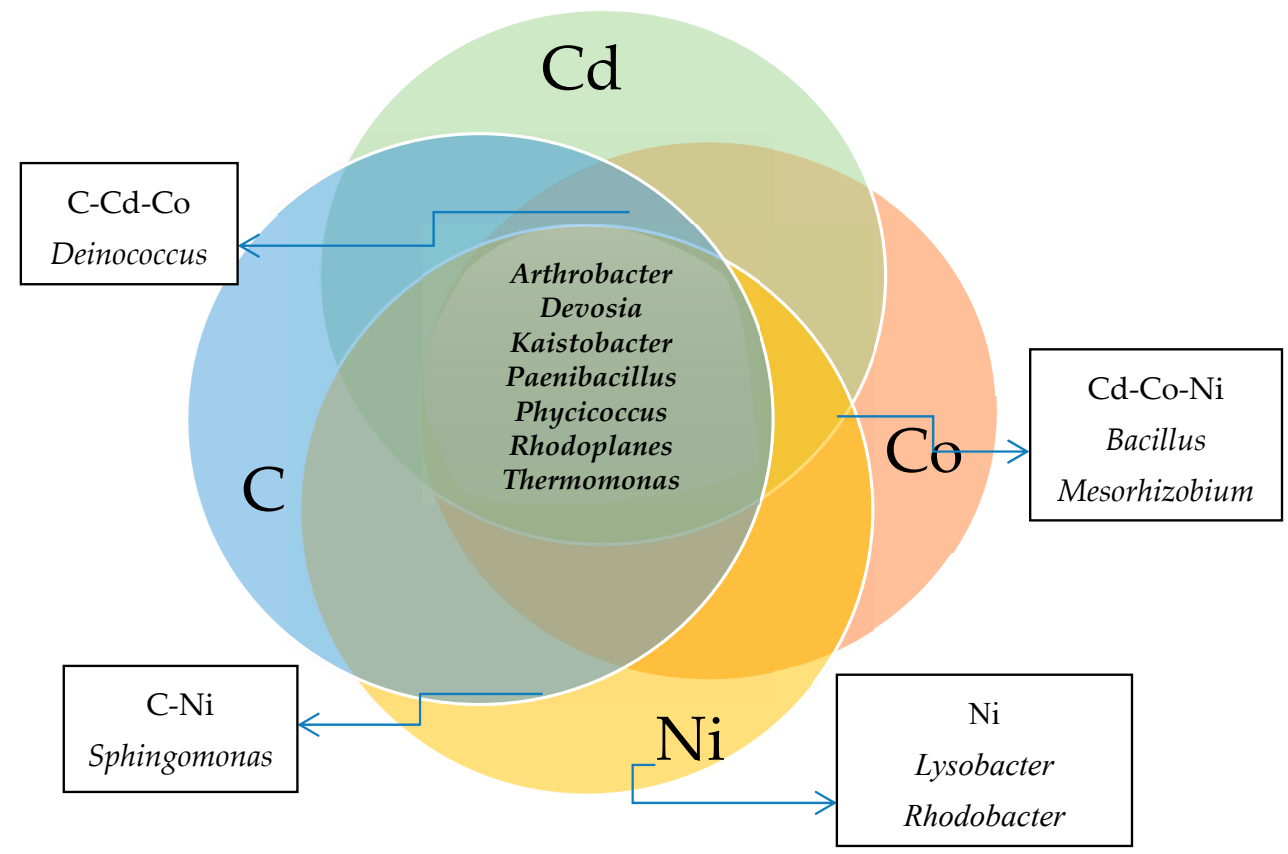

Figure 6. Venn diagram of unique and common bacterial genera where the number of specific bacterial OTUs $>1 \%$. Ccontrol soil; Cd—soil contaminated with cadmium; Co—soil contaminated with cobalt; Ni-soil contaminated with nickel. 


\section{Discussion}

Soil has a complex structure and it is a reservoir of various chemical compounds and trace elements that can disrupt the homeostasis of the soil environment. Heavy metals, including cadmium, cobalt and nickel, are toxic at high concentrations and can induce changes in the microbiological properties of soil [64]. In the present study, the calculated values of heavy metal pollution index $\left(\mathrm{IF}_{\mathrm{HM}}\right)$ confirmed that heavy metals compromised the activity of the examined microbial groups, in particular, organotrophic bacteria and fungi. Actinobacteria were least sensitive to the toxic effects of $\mathrm{Cd}^{+2}$, followed by $\mathrm{Co}^{+2}$ and $\mathrm{Ni}^{+2}$. The survival of this microbial group can probably be attributed to the acquisition of resistance to adverse environmental conditions. The physicochemical properties of soil, including $\mathrm{pH}$, sorption capacity and organic matter content, could also play a role in microbial survival [65]. Microorganisms have evolved resistance to harsh environmental conditions. Prolonged exposure to trace elements can induce changes in cell structure and lead to microbial death [66-68]. According to Sang-Hwan et al. [69], pollutants affect the rate of soil processes and can inhibit soil respiration. Microbial imbalances compromise the diversity of the soil microbiome.

Soil-dwelling microorganisms are effective indicators of soil quality [70]. Exposure to heavy metals induces changes in the proportion of $\mathrm{r}-/ \mathrm{K}$-strategists in the bacterial community. According to Sarathchandra et al. [60], an increase in the value of the CD index implies that $r$-strategists (rapidly growing microorganisms) are more abundant than $\mathrm{K}$-strategists (slowly growing microorganisms). A decrease in the value of the EP index suggests that sensitive microorganisms are replaced by microorganisms that are more resistant to soil contamination with heavy metals [59]. In the current study, the CD index for organotrophic bacteria was higher in treatments contaminated with $\mathrm{Ni}^{2+}$ and $\mathrm{Co}^{2+}$; the $\mathrm{CD}$ index for actinobacteria was higher in soil exposed to $\mathrm{Cd}^{2+}$ and $\mathrm{Co}^{2+}$; and the $\mathrm{CD}$ index for fungi was higher in treatments contaminated with $\mathrm{Co}^{2+}$ than in uncontaminated soil. The value of the EP index was highest in Actinobacteria, followed by organotrophic bacteria and fungi. In polluted regions, microbial activity also contributes to immobilization of metals in the soil environment [71,72]. Microorganisms can neutralize pollutants through their accumulation, binding and storage in the form of phosphates, oxalates and carbonates in cell structures and organelles [73,74].

Heavy metal pollution changes microbial diversity in many terrestrial ecosystems [75,76]. In this study, soil contamination with $\mathrm{Cd}^{+2}, \mathrm{Co}^{+2}$ and $\mathrm{Ni}^{+2}$ also induced changes in microbial diversity at all taxonomic levels. Bacterial phyla Actinobacteria and Proteobacteria were predominant and similar observations were by Franke-Whittle et al. [77], Sun et al. [78] and Greening et al. [79]. Proteobacteria occur not only in soils contaminated with heavy metals [80], but also in polluted waters [81] and sediments [75]. In a study by Epelde et al. [82], the proportions of microbial taxa with high metabolic plasticity, including Chloroflexi and Ktedonobacteria, increased in the bacterial community in the presence of metals. In contrast, the proportions of Actinobacteria and Acidobacteria remained stable. In the present experiment, in addition to Proteobacteria and Actinobacteria, bacterial genera of the phyla Firmicutes and Thermi were also resistant to soil contamination with $\mathrm{Cd}^{2+}, \mathrm{Co}^{2+}$ and $\mathrm{Ni}^{2+}$. Similar results were reported by Pradhan et al. [83] and Yang et al. [84] who analyzed bacterial communities in soils exposed to heavy metals. According to Emenike et al. [85], native microorganisms can effectively remove heavy metals from soil. Microorganisms develop tolerance to heavy metals by binding these contaminants on the surface of cells [86,87]. Peptidoglycan carboxyl groups are the main cationic binding sites in Gram-positive bacteria and phosphate groups-in Gram-negative bacteria [21]. In the current study, both Gram-positive and Gram-negative bacteria were identified in contaminated soil. The predominant Gram-positive bacteria were Arthrobacter, Phycicoccus, Bacillus, Paenibacillus and Deinococcus, whereas the most abundant Gram-negative bacteria were Devosia, Kaistobacter, Rhodoplanes, Thermomonas, Mesorhizobium, Lysobacter, Rhodobacter and Sphingomonas. These bacteria can be used in the bioaugmentation of soils contaminated with $\mathrm{Cd}^{2+}, \mathrm{Ni}^{2+}$ and $\mathrm{Co}^{2+}$ to restore soil homeostasis. 
Microbial tolerance to heavy metals is an individual trait. There is evidence to indicate that microorganisms survive in contaminated environments by reducing metals to a lower oxidation (less toxic) state or by binding metals with the involvement of specific and non-specific compounds that are metabolic products of microorganisms $[19,22,88,89]$. Specific compounds include metallothioneins and non-specific compounds include lowmolecular-weight organic acids, alcohols and high-molecular-weight polysaccharides [22]. De Jaysankar et al. [90] identified bacteria tolerant to $\mathrm{Hg}, \mathrm{Cd}$ and $\mathrm{Pb}$. In other studies, bacteria resistant to $\mathrm{Cr}, \mathrm{Zn}, \mathrm{Cd}, \mathrm{Pb}, \mathrm{Cu}, \mathrm{Ni}$ and $\mathrm{Co}$ were isolated from various environments contaminated with heavy metals $[91,92]$. However, microorganisms resistant to changing environmental conditions can also disrupt soil homeostasis by eliminating sensitive microorganisms. Bacteria characteristic of heavy metal-contaminated soils were also isolated in the present study. These were: Bacillus and Mesorhizobium which were predominant in treatments contaminated with $\mathrm{Cd}^{2+}, \mathrm{Co}^{2+}$ and $\mathrm{Ni}^{2+}$, as well as Lysobacter and Rhodobacter that were most abundant in soil exposed to $\mathrm{Ni}^{2+}$. The evolution of resistant bacteria decreases biodiversity in a given environment [93].

\section{Conclusions}

Contamination with $\mathrm{Ni}^{2+}, \mathrm{Co}^{2+}$ and $\mathrm{Cd}^{2+}$ disrupts the microbiological balance of soil. In the group of the analyzed heavy metals, $\mathrm{Ni}^{2+}$ induced the greatest and $\mathrm{Cd}^{+2}$ induced the smallest changes in the soil microbiome. Heavy metals contributed to changes in the values of the colony development (CD) index and the ecophysiological diversity (EP) index. Exposure to heavy metals modified the proportions of r- and K-strategists in soil. The microbial EP index was higher in treatments contaminated with heavy metals than in uncontaminated soil. The metagenomic analysis revealed that Actinobacteria and Proteobacteria were the dominant bacterial phyla. Bacteria of the genera Arthrobacter, Devosia, Kaistobacter, Paenibacillus, Phycicoccus, Rhodoplanes and Thermomonas were identified in uncontaminated soil as well as in treatments contaminated with heavy metals. These bacteria are characterized by high resistance to soil contamination with $\mathrm{Ni}^{2+}, \mathrm{Co}^{2+}$ and $\mathrm{Cd}^{2+}$.

Supplementary Materials: The following are available online at https:/ /www.mdpi.com/article/ 10.3390/min11050498/s1, Table S1: Microbial counts in soil sown with Brassica napus, Table S2: Coefficients of correlation between variables in soil sown with Brassica napus. Figure S1. The relative abundance of the dominant bacterial classes in soil. C - control soil; $\mathrm{Cd}$-soil contaminated with cadmium; $\mathrm{Co}$-soil contaminated with cobalt; $\mathrm{Ni}$-soil contaminated with nickel.

Author Contributions: E.B.-L., J.W. and J.K. framed the methodology, conceived the ideas and designed the paper E.B.-L. conducted the experiments, collected and analyzed the data. A.B. conducted the bioinformatic analysis and visualization of data. All authors contributed significantly to the discussion of the results and the preparation of the manuscript. All authors have read and agreed to the published version of the manuscript.

Funding: The results presented in this paper were obtained as part of a comprehensive study financed by the University of Warmia and Mazury in Olsztyn, Faculty of Agriculture and Forestry, Department of Soil Science and Microbiology (grant No 30.610.006-110). Project financially supported by Minister of Science and Higher Education in the range of the program entitled "Regional Initiative of Excellence" for the years 2019-2022, Project No. 010/RID/2018/19, amount of funding 12.000.000 PLN.

Data Availability Statement: The data presented in this study are available on request from the corresponding author.

Conflicts of Interest: The authors declare no conflict of interest.

\section{References}

1. Raj, S.K.; Syriac, E.K. Herbicidal effect on the bio-indicators of soil health-A review. J. Appl. Nat. Sci. 2017, 9, 2438-2448. [CrossRef]

2. Ojuederie, O.B.; Babalola, O.O. Microbial and plant-assisted bioremediation of heavy metal polluted environments: A review. Int. J. Environ. Res. Public. Health 2017, 14, 1504. [CrossRef] [PubMed] 
3. Ju, C.; Xu, J.; Wu, X.; Dong, F.; Liu, X.; Zheng, Y. Effects of myclobutanil on soil microbial biomass, respiration, and soil nitrogen transformations. Environ. Pollut. 2016, 208, 811-820. [CrossRef]

4. Borowik, A.; Wyszkowska, J. Response of Avena sativa L. and the soil microbiota to the contamination of soil with Shell diesel oil. Plant Soil Environ. 2018, 64, 102-107. [CrossRef]

5. Lombard, N.; Prestat, E.; van Elsas, J.D.; Simonet, P. Soil-specific limitations for access and analysis of soil microbial communities by metagenomics. FEMS Microbiol. Ecol. 2011, 78, 31-49. [CrossRef] [PubMed]

6. Kirpichtchikova, T.A.; Manceau, A.; Spadini, L.; Panfili, F.; Marcus, M.A.; Jacquet, T. Speciation and solubility of heavy metals in contaminated soil using X-ray microfluorescence, EXAFS spectroscopy, chemical extraction, and thermodynamic modeling. Geochim Cosmochim. Acta 2006, 70, 2163-2190. [CrossRef]

7. Adriano, D.C. Trace Elements in Terrestrial Environments: Biogeochemistry, Bioavailability and Risks of Metals, 2nd ed.; Springer: New York, NY, USA, 2003.

8. Masindi, V.; Muedi, K.L. Environmental contamination by heavy metals. In Heavy Metals; IntechOpen: London, UK, 2018. [CrossRef]

9. He, L.Y.; Zhang, Y.F.; Ma, H.Y.; Su, L.N.; Chen, Z.J.; Wang, Q.Y.; Qian, M.; Sheng, X.F. Characterization of copper-resistant bacteria and assessment of bacterial com $\mathrm{m}$ unities in rhizosphere soils of copper-tolerant plants. Appl. Soil Ecol. 2010, 44, 49-55. [CrossRef]

10. Kavamura, V.N.; Esposito, E. Biotechnological strategies applied to the decontam ination of soils polluted with heavy metals. Biotechnol. Adv. 2010, 28, 61-69. [CrossRef]

11. Blanco, P.; Hernando-Amado, S.; Reales-Calderon, J.; Corona, F.; Lira, F.; Alcalde-Rico, M.; Bernardini, A.; Sanchez, M.; Martinez, J. Bacterial multidrug efflux pumps: Much more than antibiotic resistance determinants. Microorganisms 2016, 4, 14. [CrossRef]

12. Argüello, J.M.; Raimunda, D.; González-Guerrero, M. Metal transport across biomembranes: Emerging models for a distinct chemistry. J. Biol. Chem. 2012, 287, 13510-13517. [CrossRef]

13. Hobman, J.L.; Crossman, L.C. Bacterial antimicrobial metal ion resistance. J. Med. Microbiol. 2014, 64, 471-497. [CrossRef]

14. Blindauer, C.A. Bacterial metallothioneins: Past, present, and questions for the future. J. Biol. Inorg. Chem. 2011, 16, 1011-1024. [CrossRef] [PubMed]

15. Blindauer, C.A.; Harrison, M.D.; Robinson, A.K.; Parkinson, J.A.; Bowness, P.W.; Sadler, P.J.; Robinson, N.J. Multiple bacteria encode metallothioneins and SmtA-like zinc fingers. Mol. Microbiol. 2002, 45, 1421-1432. [CrossRef]

16. Blindauer, C.A. Metallothioneins with unusual residues: Histidines as modulators of zinc affinity and reactivity. J. Inorg. Biochem. 2008, 102, 507-521. [CrossRef]

17. Fosso-Kankeu, E.; Mulaba-Bafubiandi, A.F. Implication of plants and microbial metalloproteins in the bioremediation of polluted waters: A review. Phys. Chem. Earth. 2014, 67-69, 242-252. [CrossRef]

18. Leszczyszyn, O.I.; Evans, C.D.; Keiper, S.E.; Warren, G.Z.L.; Blindauer, C.A. Differential reactivity of individual zinc ions in clusters from bacterial metallothioneins. Inorg. Chim. Acta 2007, 360, 3-13. [CrossRef]

19. Bruins, M.R.; Kapil, S.; Oehme, F.W. Microbial resistance to metals in the environment. Ecotoxicol. Environ. Saf. 2000, 45, 198-207. [CrossRef]

20. Silver, S.; Phung, L.T. Heavy metals, bacterial resistance. In Encyclopedia of Microbiology; Academic Press: London, UK, 2009; pp. 220-227.

21. Aryal, M.; Liakopoulou-Kyriakides, M. Bioremoval of heavy metals by bacterial biomass. Environ. Monit. Assess. 2015, 187, 1-26. [CrossRef] [PubMed]

22. Rajkumar, M.; Sandhya, S.; Prasad, M.N.V.; Freitas, H. Perspectives of plant-associated microbes in heavy metal phytoremediation. Biotechnol. Adv. 2012, 30, 1562-1574. [CrossRef] [PubMed]

23. Nies, D.H. Efflux-mediated heavy metal resistance in prokaryotes. FEMS Microbiol. Rev. 2003, 27, 313-339. [CrossRef]

24. Zhang, X.; Li, X.; Yang, H.; Cui, Z. Biochemical mechanism of phytoremediation process of lead and cadmium pollution with Mucor circinelloides and Trichoderma asperellum. Ecotoxicol. Environ. Saf. 2018, 157, 21-28. [CrossRef]

25. Laudicina, V.A.; Palazzolo, E.; Badalucco, L. Natural organic compounds in soil solution: Potential role as soil quality indicators. Curr. Org. Chem. 2013, 17, 2991-2997. [CrossRef]

26. Yusuf, M.; Fariduddin, Q.; Hayat, S.; Ahmad, A. Nickel: An overview of uptake, essentiality and toxicity in plants. Bull. Environ. Contam. Toxicol. 2011, 86, 1-17. [CrossRef] [PubMed]

27. Seregin, I.V.; Kozhevnikova, A.D.; Kazyumina, E.M.; Ivanov, V.B. Nickel toxicity and distribution in maize roots. Russ. J. Plant Physiol. 2003, 50, 711-717. [CrossRef]

28. Ahmad, M.S.A.; Ashraf, M. Essential roles and hazardous effects of nickel in plants. In Reviews of Environmental Contamination and Toxicology; Whitacre, D.M., Ed.; Springer International Publishing: Cham, Switzerland, 2011; pp. 125-167. [CrossRef]

29. Shafeeq, A.; Butt, Z.A.; Muhammad, S. Response of nickel pollution on physiological and biochemical attributes of wheat (Triticum aestivum L.) var. Bhakar-02. Pak. J. Bot. 2012, 44, 111-116.

30. Ali, M.B.; Vajpayee, P.; Tripathi, R.D.; Rai, U.N.; Singh, S.N.; Singh, S.P. Phytoremediation of lead, nickel, and copper by Salix acmophylla Boiss.: Role of antioxidant enzymes and antioxidant substances. Bull. Environ. Contam. Toxicol. 2003, 70, 462-469. [CrossRef] [PubMed]

31. Chatterjee, J.; Chatterjee, C. Phytotoxicity of cobalt, chromium and copper in cauliflower. Environ. Pollut. 2000, 109, 69-74. [CrossRef] 
32. Zong, H.; Liu, S.; Xing, R.; Chen, X.; Li, P. Protective effect of chitosan on photosynthesis and antioxidative defense system in edible rape (Brassica rapa L.) in the presence of cadmium. Ecotoxicol. Environ. Saf. 2017, 138, 271-278. [CrossRef]

33. Pereira de Araújoa, R.; Furtado de Almeidaa, A.-A.; Pereiraa, L.S.; Mangabeiraa, P.A.O.; Olimpio Souzaa, J.; Pirovania, C.P.; Ahnerta, D.; Baligar, V.C. Photosynthetic, antioxidative, molecular and ultrastructural responses of young cacao plants to Cd toxicity in the soil. Ecotoxicol. Environ. Saf. 2017, 144, 148-157. [CrossRef]

34. Alford, É.R.; Pilon-Smits, E.A.H.; Paschke, M.W. Metallophytes-A view from the rhizosphere. Plant Soil 2010, 337, 33-50. [CrossRef]

35. Khan, M.S.; Zaidi, A.; Wani, P.A.; Oves, M. Role of plant growth promoting rhizobacteria in the remediation of metal contaminated soils. Environ. Chem. Lett. 2009, 7, 1-19. [CrossRef]

36. Becerra-Castro, C.; Monterroso, C.; Prieto-Fernández, A.; Rodríguez-Lamas, L.; Loureiro-Viñas, M.; Acea, M.J.; Kidd, P.S. Pseudometallophytes colonising $\mathrm{Pb} / \mathrm{Zn}$ mine tailings: A description of the plant-microorganism-rhizosphere soil system and isolation of metal-tolerant bacteria. J. Hazard. Mater. 2012, 217-218, 350-359. [CrossRef]

37. Wenzel, W.W. Rhizosphere processes and management in plant-assisted bioremediation (phytoremediation) of soils. Plant Soil 2009, 321, 385-408. [CrossRef]

38. Regulation of the Minister of the Environment of 1 September 2016 Applicable in Poland (Journal of Laws 2016 item 1395 ). ISAP_Internet System of Legal Acts. Available online: http:/ / isap.sejm.gov.pl/isap.nsf/DocDetails.xsp?id=WDU20160001395 (accessed on 11 March 2020).

39. Kabata-Pendias, A.; Mukherjee, A. Trace Elements from Soil to Human; Springer: Berlin/Heidelberg, Germany, 2007.

40. Nadgórska-Socha, A.; Ptasiński, B.; Kita, A. Heavy metal bioaccumulation and antioxidative responses in Cardaminopsis arenosa and Plantago lanceolata leaves from metalliferous and non-metalliferous sites: A field study. Ecotoxicology 2013, 22, 1422-1434. [CrossRef] [PubMed]

41. Nadgórska-Socha, A.; Kandziora-Ciupa, M.; Ciepał, R. Element accumulation, distribution, and phytoremediation potential in selected metallophytes growing in a contaminated area. Environ. Monit. Assess. 2015, 187, 441. [CrossRef] [PubMed]

42. Nadgórska-Socha, A.; Kandziora-Ciupa, M.; Ciepał, R.; Barczyk, G. Robinia pseudoacacia and Melandrium album in trace elements biomonitoring and air pollution tolerance index study. Int. J. Environ. Sci. Technol. 2016, 13, 1741-1752. [CrossRef]

43. Barbieri, M. The importance of enrichment factor $(\mathrm{EF})$ and geoaccumulation index $\left(\mathrm{I}_{\text {geo }}\right)$ to evaluate the soil contamination. $J$. Geol. Geophys. 2016, 5, 237. [CrossRef]

44. Marchand, L.; Pelosi, C.; Gonzalez-Centeno, M.R.; Maillard, A.; Ourry, A.; Galland, W.; Teissedre, P.-L.; Bessoule, J.-J.; Mongrand, S.; Morvan-Bertrand, A.; et al. Trace element bioavailability, yield and seed quality of rapeseed (Brassica napus L.) modulated by biochar incorporation into a contaminated technosol. Chemosphere 2016, 156, 150-162. [CrossRef] [PubMed]

45. Adamo, P.; Dudka, S.; Wilson, M.J.; McHardy, W.J. Distribution of trace elements in soils from the Sudbury smelting area (Ontario, Canada). Water Air Soil Poll. 2002, 137, 95-116. [CrossRef]

46. Narendrula, R.; Nkongolo, K.K.; Beckett, P. Comparative soil metal analyses in Sudbury (Ontario, Canada) and Lubumbashi (Katanga, DR-Congo). Bull. Environ. Contam. Toxicol. 2012, 88, 187-192. [CrossRef] [PubMed]

47. Bacon, J.R.; Dinev, N.S. Isotopic characterisation of lead in contaminated soils from the vicinity of a non-ferrous metal smelter near Plovdiv, Bulgaria. Environ. Poll. 2005, 134, 247-255. [CrossRef]

48. Ngole, V.M.; Ekosse, G.I.E. Copper, nickel and zinc contamination in soils within the precincts of mining and landfilling environments. Int. J. Environ. Sci. Technol. 2012, 9, 485-494. [CrossRef]

49. Algreen, M.; Trapp, S.; Rein, A. Phytoscreening and phytoextraction of heavy metals at Danish polluted sites using willow and poplar trees. Environ. Sci. Poll. Res. 2014, 21, 8992-9001. [CrossRef] [PubMed]

50. Kacálková, L.; Tlustoš, P.; Száková, J. Chromium, nickel, cadmium, and lead accumulation in maize, sunflower, willow, and poplar. Pol. J. Environ. Stud. 2014, 23, 753-761.

51. Takeda, A.; Kimura, K.; Yamasaki, S.-I. Analysis of 57 elements in Japanese soils, with special reference to soil group and agricultural use. Geoderma 2004, 119, 291-307. [CrossRef]

52. Nasseem, M.G.; Abdalla, Y.H. Cobalt status in the North Western Coast Soils of Egypt in relation to cobalt content of barley for ruminants. In Proceedings of the 6th International Symposium on Environmental Biogeochemistry, Edinburgh, Scotland, 7-11 September 2003.

53. Eriksson, J.E. Concentrations of 61 Trace Elements in Sewage Sludge, Farmyard Manure, Mineral Fertilizers, Precipitation and in Oil and Crops; Swedish EPA Rep 5159; The Swedish Environmental Protection Agency: Stockholm, Sweden, 2001.

54. Trois, C.; Marcello, A.; Pretti, S.; Trois, P.; Rossi, G. The environmental risk posed by small dumps of complex arsenic, antimony, nickel and cobalt sulphides. J. Geochem. Explor. 2007, 92, 83-95. [CrossRef]

55. Smolders, E. Risk assessment of metals-Cadmium as a case study. In Assessment and Regulation of Heavy Metal Input into Agro-Ecosystem; Eckel, H., Roth, U., Döhler, H., Nicholson, F., Unwin, R., Eds.; KTBL-Schrift: Darmstadt, Germany, 2005; pp. 229-232.

56. Maslin, P.; Maier, R.M. Rhamnolipid-enhanced mineralization of phenanthrene in organic-metal co-contaminated soils. Bioremediation J. 2000, 4, 295-308. [CrossRef]

57. Khan, M.A.; Khan, A.; Alam, M. Soil contamination with cadmium, consequences and remediation using organic amendments. Sci. Total Environ. 2017, 601-602, 1591-1604. [CrossRef] 
58. Boros-Lajszner, E.; Wyszkowska, J.; Kucharski, J. Application of white mustard and oats in the phytostabilisation of soil contaminated with cadmium with the addition of cellulose and urea. J. Soils Sediments 2020, 20, 931-942. [CrossRef]

59. De Leij, F.A.A.M.; Whips, J.; Lynch, J.M. The use of colony development for the characterization of bacterial communities in soil and on roots. FEMS Microbiol. Ecol. 1993, 27, 81-97. [CrossRef]

60. Sarathchandra, S.U.; Burch, G.; Cox, N.R. Growth patterns of bacterial communities in the rhizoplane and rhizosphere of white clover (Trifolium repens L.) and perennial ryegrass (Lolium perenne L.) in long-term pasture. Appl. Soil Ecol. 1997, 6, 293-299. [CrossRef]

61. Dell Inc. Dell Statistica (Data Analysis Software System); Version 13.1; Dell Inc.: Tulsa, OK, USA, 2016.

62. Parks, D.H.; Tyson, G.W.; Hugenholtz, P.; Beiko, R.G. STAMP: Statistical analysis of taxonomic and functional profiles. Bioinformatics 2014, 30, 3123-3124. [CrossRef]

63. Krzywinski, M.I.; Schein, J.E.; Birol, I.; Connors, J.; Gascoyne, R.; Horsman, D.; Jones, S.J.; Marra, M.A. Circos: An information aesthetic for comparative genomics. Genome Res. 2009, 19, 1639-1645. [CrossRef]

64. Wyszkowska, J.; Boros-Lajszner, E.; Borowik, A.; Baćmaga, M.; Kucharski, J.; Tomkiel, M. Implication of zinc excess on soil health. J. Environ. Sci. Health. Part B 2016, 51, 261-270. [CrossRef]

65. Zaborowska, M.; Wyszkowska, J.; Kucharski, J. Microbial activity in zinc contaminates soil of different pH. Pol. J. Environ. Stud. 2006, 15, 569-574.

66. Pérez-de-Mora, A.; Burgos, P.; Madejón, E.; Cabrera, F.; Jaeckel, P.; Schloter, M. Microbial community structure and function in a soil contaminated by heavy metals: Effects of plant growth and different amendments. Soil Biol. Biochem. 2006, 38, 327-341. [CrossRef]

67. Wang, Y.P.; Shi, J.Y.; Lin, Q.; Chen, X.C.; Chen, Y.X. Heavy metal availability and impact on activity of soil microorganisms along a Cu/Zn contamination gradient. J. Environ. Sci. 2007, 19, 848-853. [CrossRef]

68. Zhou, R.; Liu, X.; Luo, L.; Zhou, Y.; Wei, J.; Chen, A.; Tang, L.; Wu, H.; Deng, Y.; Zhang, F.; et al. Remediation of Cu, Pb, Zn and Cd-contaminated agricultural soil using a combined red mud and compost amendment. Int. Biodeter. Biodeg. 2017, 118, 73-81. [CrossRef]

69. Sang-Hwan, L.; Jin-Soo, L.; Youn Jeong, C.; Jeong-Gyu, K. In situ stabilization of cadmium-, lead-, and zinc contaminated soil using various amendments. Chemosphere 2009, 77, 1069-1075. [CrossRef]

70. Serrano, A.; Tejada, M.; Gallego, M.; Gonzalez, J.L. Evaluation of soil biological activity after a diesel fuel spill. Sci. Total Environ. 2009, 407, 4056-4061. [CrossRef]

71. Masto, R.E.; Chhonkar, P.K.; Singh, D.; Patra, A.K. Alternative soil quality indices for evaluating the effect of intensive cropping, fertilisation and manuring for 31 years in the semi-arid soils of India. Environ. Monit. Assess. 2008, 136, 419-435. [CrossRef] [PubMed]

72. Narayanan, K.B.; Sakthivel, N. Biological synthesis of metal nanoparticles by microbes. Adv. Colloid. Interface Sci. 2010, 156, 1-13. [CrossRef]

73. Gadd, G.M.; Bahri-Esfahani, J.; Li, Q.; Rhee, Y.J.; Wei, Z.; Fomina, M.; Liang, X. Oxalate production by fungi: Significance in geomycology, biodeterioration and bioremediation. Fungal. Biol. Rev. 2014, 28, 36-55. [CrossRef]

74. Li, M.; Mohamed, I.; Raleve, D.; Chen, W.; Huang, Q. Field eva-luation of intensive compost application on Cd fractionation and phytoavailability in a mining-contaminated soil. Environ. Geochem. Health 2016, 38, 1193-1201. [CrossRef]

75. Yin, K.; Wang, Q.; Lv, M.; Chen, L. Microorganism remediation strategies towards heavy metals. Chem. Eng. J. 2019, 360, 1553-1563. [CrossRef]

76. Li, X.; Meng, D.; Li, J.; Yin, H.; Liu, H.; Liu, X.; Cheng, C.; Xiao, Y.; Liu, Z.; Yan, M. Response of soil microbial communities and microbial interactions to long-term heavy metal contamination. Environ. Pollut. 2017, 231, 908-917. [CrossRef] [PubMed]

77. Franke-Whittle, I.H.; Manici, L.M.; Insam, H.; Stres, B. Rhizosphere bacteria and fungi associated with plant growth in soils of three replanted apple orchards. Plant Soil 2015, 395, 317-333. [CrossRef]

78. Sun, W.; Zhang, F.; He, L.; Karthik, L.; Li, Z. Actinomycetes from the South China Sea sponges: Isolation, diversity, and potential for aromatic polyketides discovery. Front. Microbiol. 2015, 6, 1-15. [CrossRef] [PubMed]

79. Greening, C.; Carere, C.R.; Rushton-Green, R.; Harold, L.K.; Hards, K.; Taylor, M.C.; Morales, S.E.; Stott, M.B.; Cook, G.M. Persistence of the dominant soil phylum Acidobacteria by trace gas scavenging. Proc. Natl. Acad. Sci. USA 2015, 112, 10497-10502. [CrossRef] [PubMed]

80. Gołębiewski, M.; Deja-Sikora, E.; Cichosz, M.; Tretyn, A.; Wróbel, B. 16S rDNA pyrosequencing analysis of bacterial community in heavy metals polluted soils. Microb. Ecol. 2014, 67, 635-647. [CrossRef]

81. Serkebaeva, Y.M.; Kim, Y.; Liesack, W.; Dedysh, S.N. Pyrosequencing-based assessment of the bacteria diversity in surface and subsurface peat layers of a northern wetland, with focus on poorly studied phyla and candidate divisions. PLoS ONE 2013, 8, e63994. [CrossRef] [PubMed]

82. Epelde, L.; Lanzén, A.; Blanco, F.; Urich, T.; Garbisu, C. Adaptation of soil microbial community structure and function to chronic metal contamination at an abandoned Pb-Zn mine. FEMS Microbiol. Ecol. 2015, 91, 1-11. [CrossRef] [PubMed]

83. Pradhan, S.K.; Singh, N.R.; Kumar, U.; Mishra, S.R.; Perumal, R.C.; Benny, J.; Thatoi, H. Illumina MiSeq based assessment of bacterial community structure and diversity along the heavy metal concentration gradient in Sukinda chromite mine area soils, India. Ecol. Genet. Genom. 2020, 15, 100054. [CrossRef] 
84. Yang, J.; Wang, S.; Guo, Z.; Deng, Y.; Xu, M.; Zhang, S.; Yin, H.; Liang, Y.; Liu, H.; Miao, B.; et al. Spatial distribution of toxic metal(loid)s and microbial community analysis in soil vertical profile at an abandoned nonferrous metal smelting site. Int. J. Environ. Res. Public Health 2020, 17, 7101. [CrossRef] [PubMed]

85. Emenike, C.U.; Agamuthu, P.; Fauziah, S.H. Sustainable remediation of heavy metal polluted soil: A biotechnical interaction with selected bacteria species. J. Geochem. Explor. 2017, 182, 275-278. [CrossRef]

86. Ashraf, M.A.; Hussain, I.; Rasheed, R.; Iqbal, M.; Riaz, M.; Arif, M.S. Advances in microbe-assisted reclamation of heavy metal contaminated soils over the last decade: A review. J. Environ. Manag. 2017, 198, 132-143. [CrossRef] [PubMed]

87. Xu, R.; Wu, K.; Han, H.; Ling, Z.; Chen, Z.; Liu, P.; Xiong, J.; Tian, F.; Zafar, Y.; Malik, K.; et al. Co-expression of YieF and PhoN in Deinococcus radiodurans R1 improves uranium bioprecipitation by reducing chromium interference. Chemosphere 2018, 211, 1156-1165. [CrossRef]

88. Mahbub, K.R.; Subashchandrabose, S.R.; Kannan, K.; Naidu, R.; Megharaj, M. Mercury alters the bacterial community structure and diversity in soil even at concentrations lower than the guideline values. Appl. Microbiol. Biotechnol. 2017, 101, $2163-2175$. [CrossRef]

89. Pacwa-Płociniczak, M.; Płociniczak, T.; Yu, D.; Kurola, J.M.; Sinkkonen, A.; Piotrowska-Seget, Z.; Romantschuk, M. Effect of Silene vulgaris and heavy metal pollution on soil microbial diversity in long-term contaminated soil. Water Air Soil Pollut. 2018, 229, 1-13. [CrossRef]

90. De, J.; Ramaiah, N.; Vardanyan, L. Detoxification of toxic heavy metals by marine bacteria highly resistant to mercury. Mar. Biotechnol. 2008, 10, 471-477. [CrossRef] [PubMed]

91. Abioye, O.P.; Oyewole, O.A.; Oyeleke, S.B.; Adeyemi, M.O.; Orukotan, A.A. Biosorption of lead, chromium and cadmium in tannery effluent using indigenous microorganisms. Braz. J. Biol. Sci. 2018, 5, 25-32. [CrossRef]

92. Ashruta, A.G.; Nanoty, V.; Bhalekar, U. Biosorption of heavy metals from aqueous solution using bacterial EPS. Int. J. Life Sci. 2014, 2, 373-377.

93. Lock, K.; Janssen, C.R. Influence of soil zinc concentrations on zinc sensitivity and functional diversity of microbial communities. Environ. Pollut. 2005, 136, 275-281. [CrossRef] [PubMed] 